\title{
A QUALITY CONTROL SCHEME FOR A COMMERCIAL POZZOLANA PLANT: A CASE STUDY OF POZZOLANA GHANA LTD
}

\author{
J. Sarfo-Ansah*, K. A. Boakye, E. Atiemo And R. Appiah \\ (J. S. A.: Ciments de l'Afrique, Ghana; K. A. B. \& E. A.: Building Materi- \\ als Development Division, Building and Roads Research Institute (BRRI), \\ Council for Scientific and Industrial Research (CSIR), Kumasi, Ghana; R. A.: \\ Quality Control Section, Pozzolana Ghana Ltd, Gomoa Mprumem, Ghana). \\ *Corresponding author's email: James.Sarfo@cimentsafrique.com
}

\begin{abstract}
A Quality control scheme was developed for a 200 ton per day commercial pozzolana plant. The scheme was evaluated for the first 34 days of production. Statistical Process Control techniques were specifically applied to the mechanical properties of setting times and compressive strength. Results obtained showed that pozzolana samples tested were chemically suitable with total $\mathrm{SiO}_{2}, \mathrm{Al}_{2} \mathrm{O}_{3}$ and $\mathrm{Fe}_{2} \mathrm{O}_{3}$ content $\geq 70 \%$. Mechanical tests performed were mostly under control and when out-of-control, they gave valuable indication to plant malfunction or operator errors which were promptly corrected. The results of mechanical properties tested against the three major brands of cement on the Ghanaian market showed that pozzolana gave highest compressive strengths with Dangote CEM I 42.5R ranging between $21.3 \mathrm{MPa}-36.3$ $\mathrm{MPa}$ at 7 days and $33.8 \mathrm{MPa}-45.1 \mathrm{MPa}$ at 28 days whilst lowest compressive strengths were obtained with Ghacem CEM II B-L 32.5R cement ranging between $16.3 \mathrm{MPa}-23.6 \mathrm{MPa}$ at 7 days and $23.3 \mathrm{MPa}-30.7 \mathrm{MPa}$ at 28 days. Compressive strengths obtained with Diamond CEM II B-L $42.5 \mathrm{~N}$ cement were average. A mean compressive strength for all brands of cement of $25.2 \mathrm{MPa}$ and $33.6 \mathrm{MPa}$ at 7 days and 28 days respectively were obtained.
\end{abstract}

Keywords: Pozzolana cement, statistical process control, Shewhart chart, compressive strength, setting time

\section{Introduction}

Ghana's housing construction sector has been plagued by high cost of imported inputs-especially Portland cement and its derivatives (Sarfo-Ansah et al., 2009). Several locally developed materials have been proposed as alternatives and partial replacement of Portland cement. Such materials include burnt bricks (Obeng, 1993), compressed lateritic blocks
(Gidigasu \& Bawa, 1965), lime (Hagan, 1988) and pozzolanas - from bauxite waste (Hammond, 1974) and clay (Atiemo, 2005).

Clay pozzolana in particular has received much attention due to the widespread availability of clay, the main raw material for its production nationwide (Kesse, 1985). After 30 years of research and field trials into clay pozzolanas, the Building and Road Research 
Institute (BRRI) of the Council for Scientific and Industrial Research (CSIR-Ghana) transferred the clay pozzolana production technology to PMC Global Inc. who subsequently established a 200 ton per day pozzolana plant - Pozzolana Ghana Ltd at Gomoa Mprumem in the Central region of Ghana to commercialize clay pozzolana. For such an entry level product as clay pozzolana on the Ghanaian market, there was a need to develop an effective and easily adaptable quality control scheme to ensure high quality standards of the product and optimal productivity levels of the plant. Quality control in manufacturing describes the individual measures which relate to the monitoring and control of particular production processes geared at ensuring the totality of features and characteristics of a product that bears on its ability to satisfy given needs (American Management System, 2010). Tools and techniques employed to control quality include statistical techniques such as Design of Experiments (DoE), Taguchi methods, Failure Mode Experimental Analysis (FMEA) and Statistical Process Control (SPC) (Hairulliza et al., 2009). SPC is the most employed quality control tool in manufacturing due to its easy adaptability (McAvoy, 2002).

SPC uses statistical concepts of the mean $\bar{x}$ and the standard deviation, $\sigma$, to characterize a normal distribution of the measured variable (Edgar et al., 1999) by isolating the assignable variability of the system from the inherent variability or noise of the system (Berthouex, 1989). Improved process operation then results from correcting the abnormal assignable variability (McAvoy, 2002). One way of achieving this is through the use of control charts such as the Shewhart chart. A control chart is a graphical representation on which values of quality characteristics under review are plotted sequentially based on a tar- get value and quality limits. Two quality limits are of particular significance on a Shewhart chart - the warning limits defined as $\bar{x} \pm 2 \sigma$ and action limits defined as $\bar{x} \pm 3 \sigma$ (Koech, 2010).

Control charts are applied in SPC for two reasons. First, in indirect control, to help bring a process for which very little information exists into a state of statistical control and second, in direct control, by keeping variation about a target level to the barest minimum for a process which is already in a state of statistical control (Berthouex, 1989). In manufacturing, control charts are applied more especially for the latter reason (Hairulliza et al., 2009) with the basic assumption that typical process performance is defined by a constant value and the residuals about this level are random, independent and of a constant variance (Berthouex, 1989). Shewhart charts also find applicability in clinical chemistry (Westgard et al., 1981), analytical chemistry (Taverniers et al., 2004) and waste water treatment (Berthouex, 1981).

\section{Experimental}

A 200 TPD (tonnes per day) commercial pozzolana plant of Pozzolana Ghana Ltd, located at Gomoa Mprumem was used for the study. Production of pozzolana started at the plant on $18^{\text {th }}$ April, 2011. Fig. 1 shows the flow chart for the 200 TPD plant. A scheme of sampling was developed for the pozzolana production process as shown in Fig. 2. The hourly milled pozzolana samples taken were formed into a daily composite sample to determine the mechanical and chemical properties of the pozzolana. The pozzolanas were tested for mechanical and chemical properties with the three main brands of Portland cement on the Ghanaian market - Ghacem CEM II B-L Class 32.5R, Diamond CEM II B-L Class $42.5 \mathrm{~N}$ and Dangote CEM I Class 42.5R cements - by replacing $33 \%$ of the cements with pozzolana. 
Test methods for mechanical properties of the pozzolana cement were based on the Ghana Standards, GS C 311-05 and where necessary on EN 196:1-4. Chemical tests were based on gravimetric methods stipulated in ASTM C 150. Internally adopted criteria were developed for sorting of the calcined nodules. These tests were compiled into a set of Standard Operating Procedures (SOPs) for easy use by lab- oratory technicians. As much as possible, the laboratory applied the principles enshrined in ISO 17025 standards. In conformity with that, a draft quality manual was produced and adopted for use in the laboratory. Test results for mechanical properties were developed into Shewhart charts to ascertain the quality control dynamics of the production process.

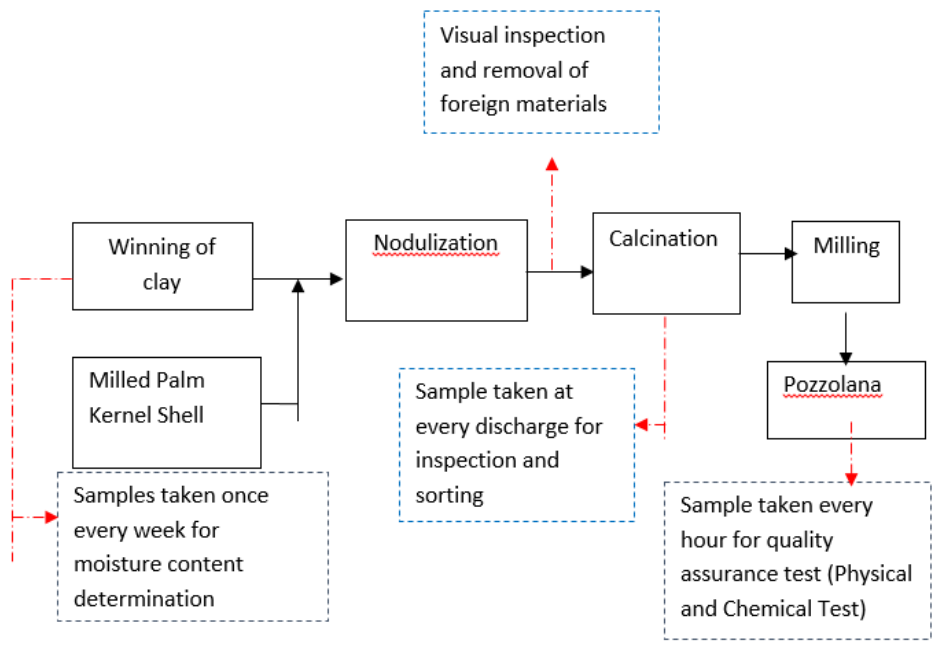

Fig. 1: Flow chart for 200 TPD plant.

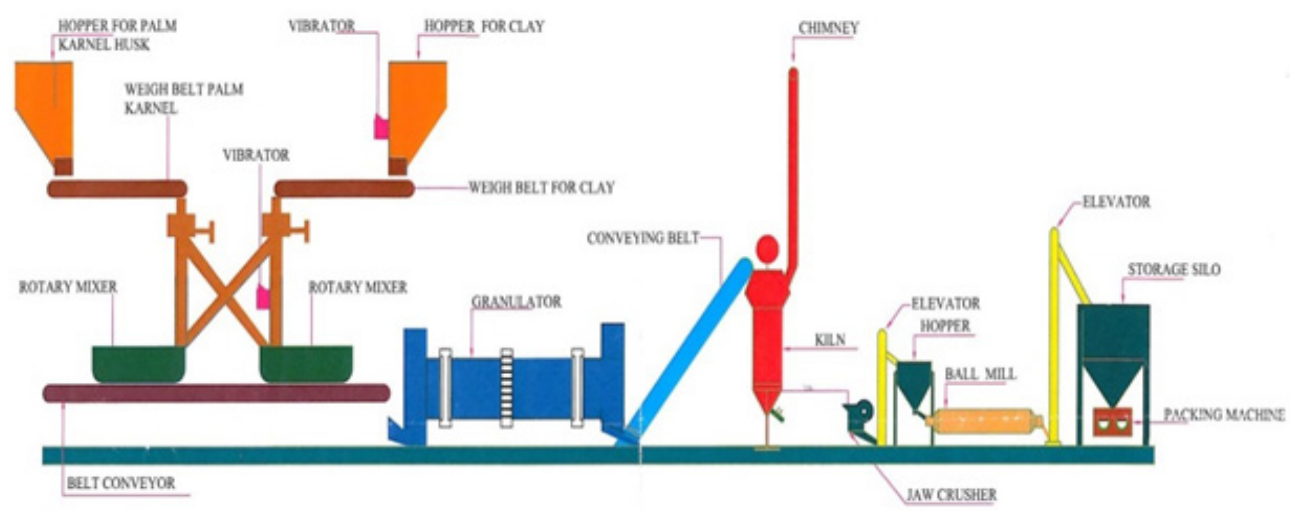

Fig. 2: Schematic representation of production process showing sampling points for quality control. 


\section{Chemical analysis}

The quality benchmark for chemical suitability of pozzolanas produced was standard levels as stipulated in EN 197-1 and ASTM C 618. Table 1 shows chemical determinations of some pozzolana samples produced at the plant. All the pozzolana samples analysed within the period were found to be chemically suitable with total $\mathrm{SiO}_{2}+\mathrm{Al}_{2} \mathrm{O}_{3}+\mathrm{Fe}_{2} \mathrm{O}_{3}$ contents higher than the minimum $70 \%$ required in ASTM
C618. The $\mathrm{SiO}_{2}$ content of all the pozzolanas exceeded the minimum limit of $25.0 \%$ (averaging $63.36 \%$ ) as prescribed by EN 197-1. The loss on ignition figures determined were also below the maximum limit of $5.0 \%$ with an average of $3.45 \%$; the chloride contents were less than $0.1 \%$ and the sulphate contents (determined as $\mathrm{SO}_{3}$ ) were less than $3.5 \%$ required of pozzolanas as specified in EN 197-1.

TABLE 1

Chemical properties of samples of pozzolana produced between April-August, 2012

\begin{tabular}{|c|c|c|c|c|c|c|c|c|c|}
\hline $\begin{array}{c}\text { DATE } \\
2012\end{array}$ & $\begin{array}{l}\text { LOI } \\
\%\end{array}$ & $\begin{array}{l}\mathrm{SiO}_{2} \\
\%\end{array}$ & $\begin{array}{l}\mathrm{Al}_{2} \mathrm{O}_{3} \\
\%\end{array}$ & $\begin{array}{l}\mathrm{Fe}_{2} \mathrm{O}_{3} \\
\%\end{array}$ & $\begin{array}{l}\mathrm{CaO} \\
\%\end{array}$ & $\begin{array}{l}\text { MgO } \\
\%\end{array}$ & $\begin{array}{l}\mathrm{Cl} \\
\% \mathrm{~A}\end{array}$ & $\begin{array}{l}\text { Insolube } \\
\text { Residue } \\
\%\end{array}$ & $\begin{array}{l}\mathrm{SO}_{3} \\
\%\end{array}$ \\
\hline $26 / 4$ & 3.72 & 63.80 & 18.93 & 5.41 & 0.18 & 1.08 & 0.01 & 1.42 & 2.02 \\
\hline $28 / 4$ & 4.02 & 63.43 & 18.06 & 5.51 & 0.10 & 1.12 & 0.01 & 1.36 & 1.18 \\
\hline $30 / 4$ & 3.88 & 62.98 & 18.84 & 5.19 & 0.14 & 1.24 & 0.01 & 1.44 & 2.01 \\
\hline $2 / 5$ & 3.85 & 62.69 & 17.93 & 5.86 & 0.11 & 1.04 & 0.01 & 1.31 & 1.15 \\
\hline $3 / 5$ & 3.61 & 63.92 & 17.82 & 5.18 & 0.10 & 1.14 & 0.01 & 1.29 & 1.19 \\
\hline $5 / 5$ & 3.92 & 63.88 & 18.15 & 5.78 & 0.18 & 1.06 & 0.01 & 1.40 & 2.01 \\
\hline $7 / 5$ & 3.55 & 62.96 & 19.04 & 5.49 & 0.20 & 1.30 & 0.01 & 1.20 & 2.04 \\
\hline $8 / 5$ & 3.71 & 63.00 & 19.11 & 4.97 & 0.09 & 1.16 & 0.01 & 1.32 & 2.00 \\
\hline $9 / 5$ & 2.98 & 63.90 & 18.65 & 5.44 & 0.13 & 1.28 & 0.01 & 1.40 & 1.26 \\
\hline $10 / 5$ & 2.86 & 63.41 & 18.04 & 5.20 & 0.11 & 1.24 & 0.01 & 1.33 & 1.62 \\
\hline $11 / 5$ & 3.27 & 62.95 & 18.62 & 5.18 & 0.16 & 1.08 & 0.01 & 1.30 & 1.18 \\
\hline $27 / 6$ & 2.99 & 63.97 & 18.01 & 5.68 & 0.13 & 1.14 & 0.01 & 1.34 & 2.03 \\
\hline $28 / 6$ & 3.42 & 63.41 & 18.18 & 5.10 & 0.18 & 1.12 & 0.01 & 1.41 & 1.84 \\
\hline $5 / 8$ & 3.51 & 63.00 & 18.92 & 4.96 & 0.12 & 1.16 & 0.01 & 1.36 & 1.91 \\
\hline $6 / 8$ & 3.88 & 63.11 & 18.04 & 5.32 & 0.14 & 1.20 & 0.01 & 1.30 & 1.52 \\
\hline $7 / 8$ & 2.85 & 63.91 & 18.65 & 5.56 & 0.18 & 1.28 & 0.01 & 1.42 & 1.62 \\
\hline $8 / 8$ & 3.07 & 62.89 & 19.02 & 5.48 & 0.16 & 1.24 & 0.01 & 1.28 & 1.36 \\
\hline $9 / 8$ & 3.00 & 63.19 & 18.94 & 5.39 & 0.16 & 1.18 & 0.01 & 1.33 & 1.64 \\
\hline $10 / 8$ & 2.83 & 62.54 & 18.34 & 5.35 & 0.14 & 1.04 & 0.01 & 1.30 & 1.52 \\
\hline $14 / 8$ & 3.04 & 63.54 & 18.45 & 5.63 & 0.13 & 1.12 & 0.01 & 1.34 & 1.62 \\
\hline $15 / 8$ & 2.65 & 63.24 & 18.05 & 5.24 & 0.16 & 1.05 & 0.01 & 1.29 & 1.43 \\
\hline $4 / 9$ & 3.65 & 63.14 & 18.54 & 5.26 & 0.16 & 1.06 & 0.01 & 1.36 & 1.37 \\
\hline $6 / 9$ & 3.55 & 62.65 & 18.26 & 5.26 & 0.13 & 1.12 & 0.01 & 1.42 & 1.42 \\
\hline $8 / 9$ & 3.23 & 63.04 & 18.59 & 5.28 & 0.09 & 1.06 & 0.01 & 1.36 & 1.64 \\
\hline $12 / 9$ & 3.14 & 62.36 & 18.31 & 5.31 & 0.12 & 1.09 & 0.01 & 1.44 & 1.15 \\
\hline $18 / 9$ & 2.85 & 63.53 & 18.39 & 5.76 & 0.15 & 1.24 & 0.01 & 1.42 & 1.23 \\
\hline $21 / 9$ & 3.04 & 62.37 & 18.32 & 5.64 & 0.12 & 1.27 & 0.01 & 1.28 & 1.23 \\
\hline $22 / 9$ & 2.86 & 63.64 & 18.35 & 5.12 & 0.16 & 1.05 & 0.01 & 1.33 & 1.15 \\
\hline $23 / 9$ & 3.12 & 63.75 & 18.35 & 5.54 & 0.09 & 1.25 & 0.01 & 1.32 & 2.03 \\
\hline $4 / 10$ & 3.31 & 63.84 & 18.32 & 5.23 & 0.16 & 1.26 & 0.01 & 1.40 & 1.84 \\
\hline $6 / 10$ & 3.18 & 63.36 & 18.27 & 5.63 & 0.13 & 1.06 & 0.01 & 1.34 & 2.02 \\
\hline $8 / 10$ & 2.86 & 62.86 & 18.49 & 5.34 & 0.12 & 1.15 & 0.01 & 1.41 & 1.18 \\
\hline $16 / 10$ & 3.42 & 62.95 & 18.84 & 5.24 & 0.16 & 1.18 & 0.01 & 1.33 & 2.01 \\
\hline $17 / 10$ & 2.87 & 63.42 & 18.13 & 5.24 & 0.15 & 1.15 & 0.01 & 1.32 & 1.45 \\
\hline Average & 3.29 & 63.25 & 18.44 & 5.38 & 0.14 & 1.15 & 0.01 & 1.35 & 1.58 \\
\hline
\end{tabular}

\section{Setting times}

Figs. 3 and 4 are shewhart charts showing the initial setting times and final setting times of the pozzolanas tested within the period. Pozzolana set quickest with DC than other cement brands on the market. DM based pozzolana ce- ment set between DC and GC based pozzolana cement with GC based pozzolana cement setting as an average of the three brands of the cement. The effect of limestone in GC and DM on the pozzolanic reaction results in their slow rate of setting. All the samples tested passed 
the GS 803 standard of $60 \mathrm{~min}$ for initial setting time and $600 \mathrm{~min}$ for final setting time. On occasions when the pozzolana cement samples set quicker than the lower warning limit with DC, investigations with production team showed that the mill was being underfed due to a faulty ratchet feeder leading to increased pozzolana fineness. The mill was shut down for corrective maintenance on the ratchet feeder. This helped in controlling the energy expenditure of the mill.

The reduced setting times also gave an earlier indication of the problem associated with the mill than the compressive strength determinations which would only be due after 7 and 28 days. Thus, problems with production could be more promptly attended to.

\section{Compressive strengths}

Fig. 5 and 6 show the 7-days and 28-days compressive strengths of the pozzolanas produced within the period. Generally, all pozzolana samples tested satisfied the 7-day minimum requirement of $16 \mathrm{MPa}$ stipulated in GS 803:2000 and EN 197:2000. None of the samples tested fell below the lower warning or action limits which would require corrective measures to be taken. Whenever compressive strengths fell below the lower warning limit as on 3/5/12 and 15/8/12 respectively for 28 days strength (Fig. 6), the tests were repeated for confirmation and production staff notified accordingly to maintain best production standards.

Strength gains were lowest for Ghacem CEM II B-L Class 32.5R based pozzolana cements, followed by Diamond CEM II B-L Class $42.5 \mathrm{~N}$ based pozzolana cement samples whilst Dangote CEM I Class 42.5R based pozzolana cement samples attained the highest compressive strengths. Diamond CEM II B-L class $42.5 \mathrm{~N}$ based samples performed usually as average cement.

The lower strengths attained by the CEM II B-L samples is mainly due to part of the cements already substituted an inert filler - limestone. This limits the amount of free calcium hydroxide available for the pozzolanic reaction to take place and hence negatively imparts the strength development. This low strength development was also evidenced by a higher level of customer complaints received by the laboratory from customers who used the product with Ghacem CEM II B-L 32.5R especially. More significantly, Pozzolana cement samples prepared with Ghacem CEM II B-L 32.5R failed to meet the GS 803:2000 and the EN 197-1:2000 requirements as shown in Fig. 3 for all samples tested. Customers were often advised to use either Dangote CEM I class $42.5 \mathrm{R}$ or Diamond CEM I class $42.5 \mathrm{~N}$ as much as possible. 


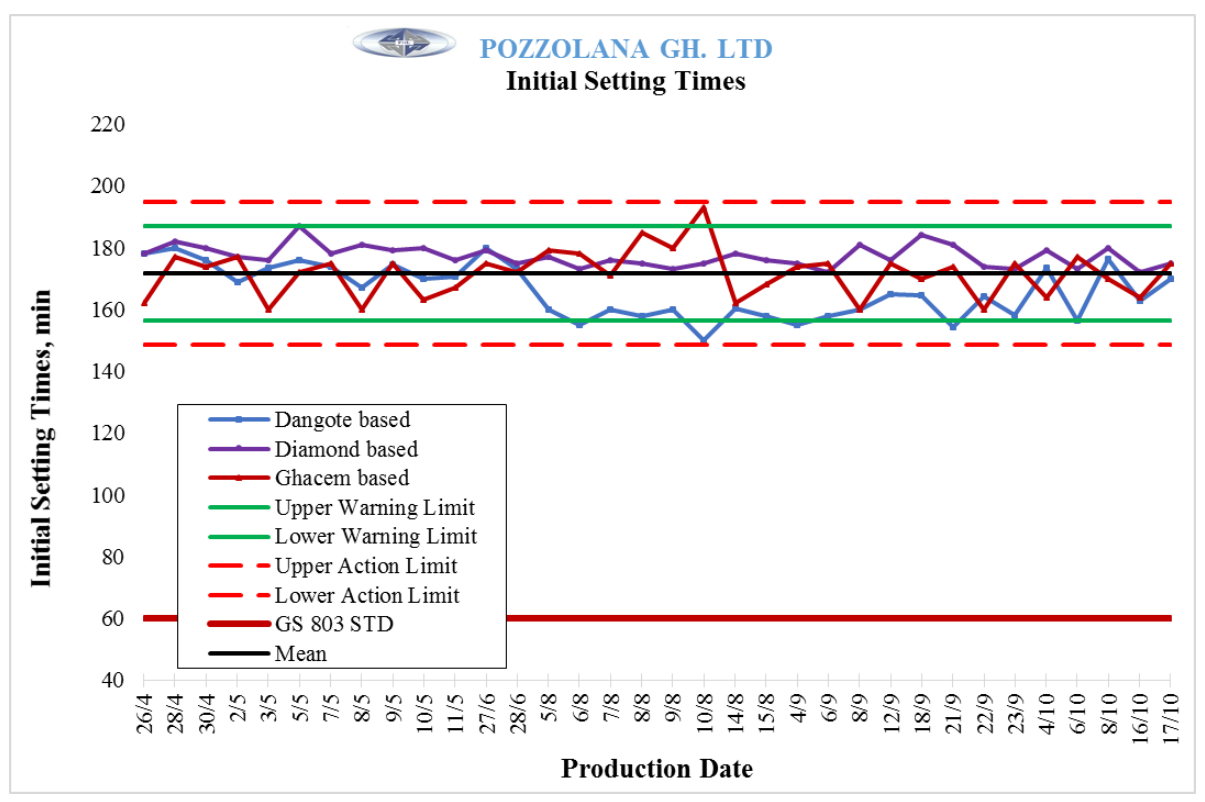

Fig. 3: Shewhart chart showing initial setting times of some pozzolana samples produced between April-October, 2012 with major brands of cement.

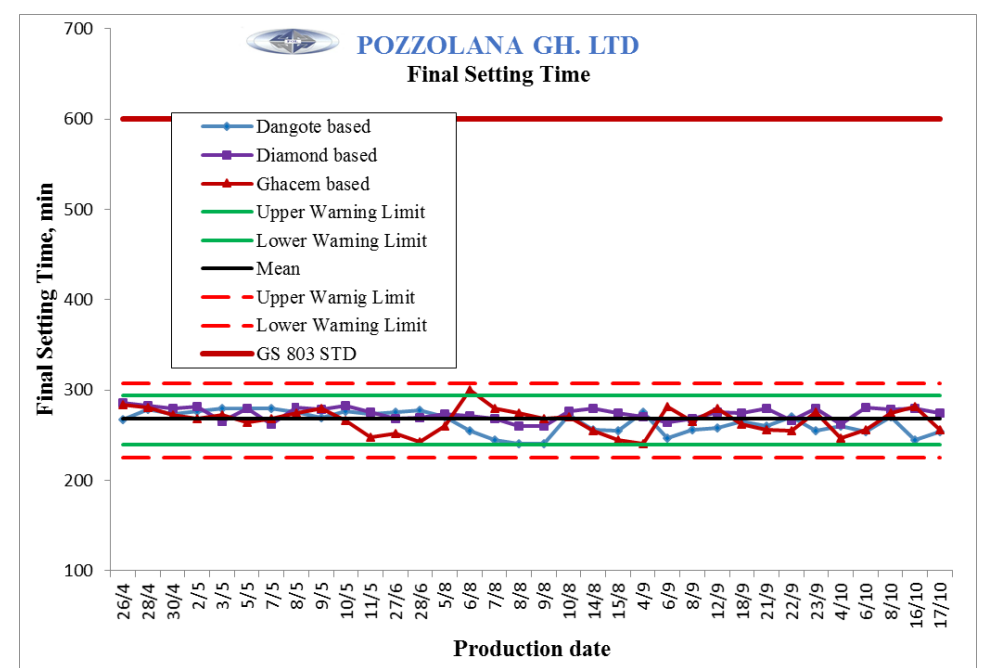

Fig. 4: Shewhart chart showing final setting times of some pozzolana samples produced between April-October, 2012 with major brands of cement. 


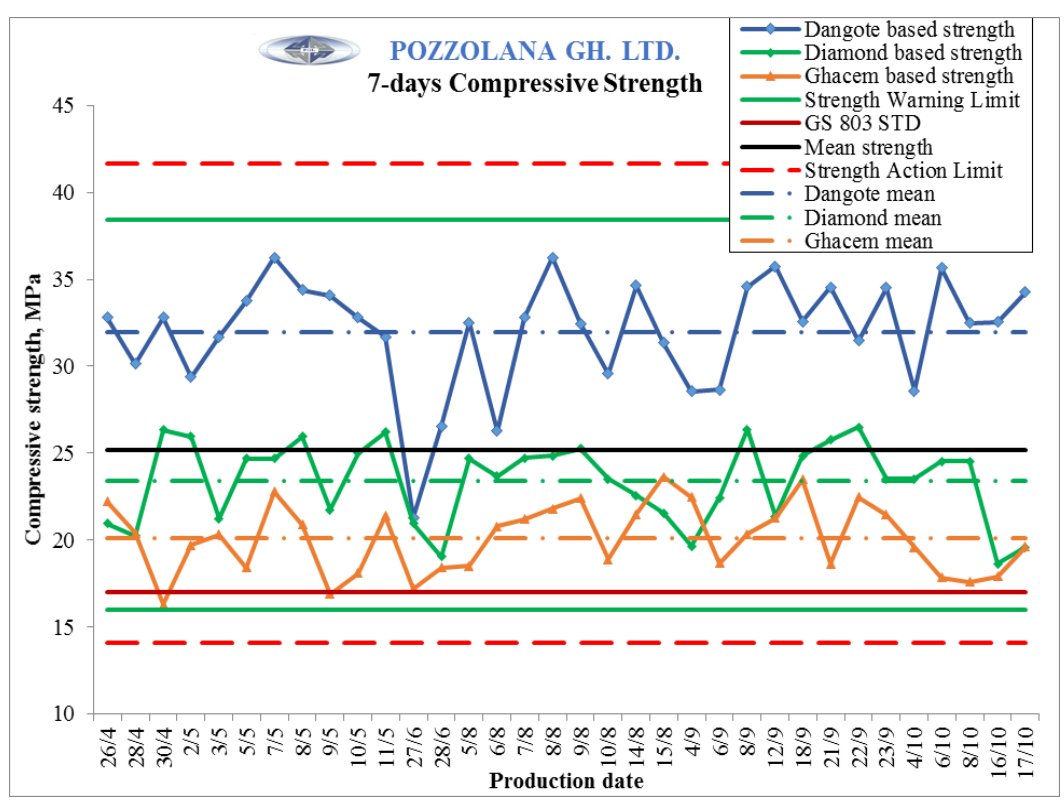

Fig. 5: Shewhart chart showing 7day compressive strengths of some pozzolana samples produced between April - October, 2011 with major brands of cement.

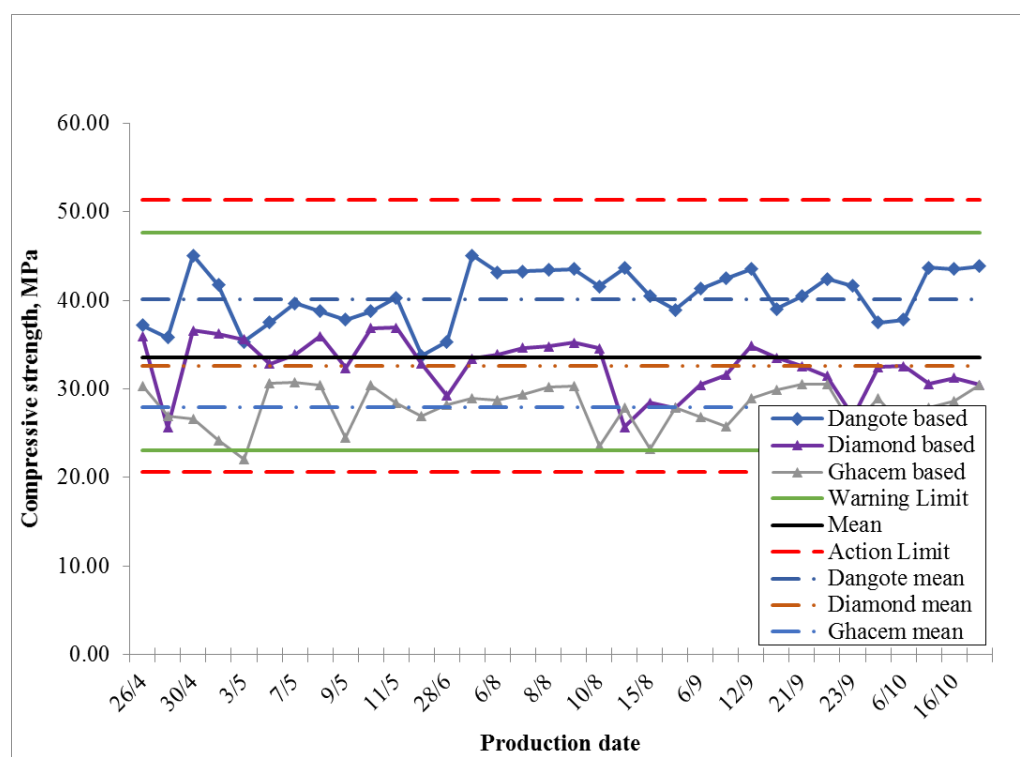

Fig. 6: Shewhart chart showing 28-day compressive strengths of some pozzolana samples produced between April -October, 2011 with major brands of cement. 
Clay moisture content and kiln product quality

TABLE 2

Clay moisture content and kiln discharge sorting analysis

\begin{tabular}{|c|c|c|c|c|c|c|}
\hline \multirow[t]{3}{*}{ DATE } & DISCHARGE & TOTAL & MASS & $\%$ & \multirow{3}{*}{$\begin{array}{l}\text { ACTION } \\
\text { TAKEN }\end{array}$} & MOISTURE \\
\hline & SAMPLE TIME & MASS & REJECT & REJECT & & CONTENT (\%) \\
\hline & (GMT) & g & g & $\leq 40$ & & $\geq 15$ \\
\hline \multirow[t]{2}{*}{$26 / 4 / 11$} & $14: 50$ & 1263 & 131 & 10.37 & & \multirow{6}{*}{18.60} \\
\hline & $16: 35$ & 1220.5 & 192 & 15.73 & & \\
\hline \multirow[t]{4}{*}{$28 / 4 / 11$} & 9:20 & 1155 & 232 & 20.09 & & \\
\hline & $10: 30$ & 1133.5 & 383 & 37.79 & Milled & \\
\hline & $12: 40$ & 1792 & 471.2 & 36.29 & Milled & \\
\hline & $15: 40$ & 1221 & 577.3 & 37.28 & \multirow[t]{3}{*}{ Milled } & \\
\hline \multirow[t]{3}{*}{$30 / 4 / 11$} & $11: 30$ & 938 & 305 & 32.52 & & \multirow{6}{*}{15.20} \\
\hline & 14:00 & 1146 & 232 & 20.24 & & \\
\hline & $15: 50$ & 1472 & 657 & 44.63 & \multirow{15}{*}{$\begin{array}{l}\text { Product } \\
\text { rejected }\end{array}$} & \\
\hline \multirow[t]{3}{*}{ 02/05/11 } & 9:15 & 1462 & 273.5 & 18.71 & & \\
\hline & $10: 40$ & 1184 & 203 & 17.15 & & \\
\hline & $13: 00$ & 1336.5 & 311 & 23.27 & & \\
\hline \multirow[t]{6}{*}{ 03/05/11 } & 8:40 & 1478.5 & 232 & 15.69 & & \\
\hline & 10:00 & 1647 & 110.5 & 6.71 & & \\
\hline & $11: 30$ & 1786 & 248.5 & 13.91 & & \\
\hline & 13:05 & 1258 & 205 & 16.30 & & \\
\hline & $14: 24$ & 1488 & 224 & 15.05 & & \\
\hline & $15: 40$ & 1364 & 215 & 15.76 & & \\
\hline \multirow[t]{5}{*}{ 05/05/11 } & $9: 10$ & 2235 & 426 & 19.06 & & \\
\hline & $11: 55$ & 1434 & 306 & 21.34 & & \\
\hline & 13:05 & 1227 & 346 & 28.20 & & \\
\hline & $14: 30$ & 1134.5 & 301 & 26.53 & & \\
\hline & 16:05 & 1164 & 251 & 21.56 & & \\
\hline \multirow[t]{5}{*}{$07 / 05 / 11$} & 9:10 & 1632 & 408.0 & 25.00 & & \\
\hline & $10: 30$ & 1404.0 & 415.0 & 29.56 & & 15.00 \\
\hline & $12: 00$ & 1378.0 & 580.0 & 42.09 & \multirow{3}{*}{$\begin{array}{l}\text { Product } \\
\text { rejected }\end{array}$} & \\
\hline & $13: 10$ & 1198.0 & 344.0 & 28.71 & & \\
\hline & $15: 30$ & 1288.0 & 432.0 & 33.54 & & \\
\hline
\end{tabular}


Table 2 shows data of some kiln output analysis and clay moisture content determinations made during the period. Reject nodules from the kiln included under burnt and over burnt nodules from the kiln. On occasions when the percentage of reject product exceeded $40 \%$, the product was rejected and thrown away. Production team were informed of the rejected product and stricter control of the kiln fire and palm kernel shell content in raw meal was enforced. The maintenance team was also tasked to ensure optimum performance of kiln blowers. On 28/4/11 the percentage rejects were high but the material was not rejected. This led to lower 7-day and 28-day compressive strengths with all brands of cement as shown on Figs. 4 and 5. The moisture content informed production team on right quantity of palm kernel shells to be added to the clay for effective firing. When the moisture content of the raw clay was lower than $15 \%$, water was added at the nodulization stage to ensure proper mixing and nodules formation.

\section{Conclusion}

The quality control scheme employed for the pozzolana plant covered most major production operations of the plant. Methods of analysis employed in the quality control process were standard and consistent with internationally accepted practices in cement plants. Chemical analysis showed that the products of the plant were chemically suitable as pozzolanas. All pozzolana samples tested set within the Ghana Standard GS 803 limits for initial and final setting times.

The 7-days and 28-days compressive strengths of pozzolana samples tested with the three major brands of Portland cement on the Ghanaian market indicated that pozzolana gave the highest compressive strengths when used with Dangote CEM I 42.5R cement with a mean 7-day compressive strength of $32.0 \mathrm{MPa}$ and a mean 28-day compressive strength of $40.5 \mathrm{MPa}$. The lowest compressive strengths were always obtained by using pozzolana with Ghacem CEM II B-L 32.5R cement with a mean 7-day compressive strength of 20.1 $\mathrm{MPa}$ and a mean 28-day compressive strength of $28.0 \mathrm{MPa}$ which is lower than the GS 803 minimum standard of $32.5 \mathrm{MPa}$. Compressive strengths obtained using pozzolana with Diamond CEM II B-L $42.5 \mathrm{~N}$ were between those of Dangote CEM I 42.5R and Ghacem CEM II B-L 32.5R with mean 7-day strength of 23.4 $\mathrm{MPa}$ and 28-day strength of $32.6 \mathrm{MPa}$.

The quality control scheme also helped in early detection of mechanical malfunctions of key equipment such as the kiln and ball mill so that necessary repair works would be carried out in a timely manner. Operator errors were also brought to the fore as early as possible by the results of the quality control mechanism whilst customer complaints could be anticipated and handled more efficiently.

\section{References}

AMERICAN SOCIETY FOR TESTING AND MATERIALS (2000) 2000 annual book of ASTM standards: Part 14-C 150; Specification for ordinary Portland cement, p. 101-107. ASTM, Philadelphia

Aтіемo, E. (2005) Production of pozzolana from some local clays: prospects for application in housing construction. Biennial Journal of Building and Road Research Inst. 9 (1\&2), 34.

Berthouex, P. M. (1989) Constructing control charts for wastewater treatment plant operation. Research Journal of the Water Pollution Control Federation 61 (9\&10), 1534.

Edgar, T.F., Smith, C. L., Shinskey, F. G., Gassman, G. W., Schafbuch, P. J., Mcavoy, T. J. \& SeBORG, D. E. (1973) Process Control. Section 8 
in: Chemical engineers' handbook, $6^{\text {th }}$ ed., p: 21. McGraw-Hill Book Co. New York.

EUROPEAN STANDARD EN 196-1 (2000) Methods of testing cement: Determination of strength, p: 1 - 36. European Committee for Standardization, Brussels.

\section{EUROPEAN STANDARD EN 196-3 (2000) Methods} of testing cement: Determination of setting times and soundness, p: $1-18$. European Committee for Standardization, Brussels.

\section{EUROPEAN STANDARD EN 196-4 (2000) Methods} of testing cement: Quantitative determination of constituents, p: 1 - 38. European Committee for Standardization, Brussels.

GHANA STANDARD GS C311-05 (2009) Standard test methods for sampling and testing fly ash or natural pozzolana for use in Portland cement concrete. p: 1 - 9. Ghana Standards Authority, Accra.

GHANA STANDARD GS 803 (2009) Building and construction materials- specification for Portland Pozzolana cement - calcined clay based. Ghana Standards Authority, Accra.

Gidigasu, M. D. \& Bawa, N. S. (1965) Use of stabilized soil as a building material. BRRI Current Research Note, 19, 1

Hagan, E. B. (1988) Establishment of a small lime production works in support of construction - related interventions in the Eastern Region, Ghana, p: $1-86$. Government of Ghana/UNHCS
Hairulliza, M. J, Ruzzakiah, J. \& Genasan, D. (2009) Quality control in manufacturing companies: motivating factors and challenges. p. $495-$ 508. Retrieved on 16/09/2013 from http:// www.intechopen.com

Hammond, A. A. (1974) Pozzolana from bauxite waste. Proceedings of Conference on the achievement of Cost Reduction in Public Construction, Accra, Ghana, 4/5b, 18

Kesse, G. O. (1985) The mineral and rock resources of Ghana, p: 416 - 426. A.A Balkena Rotterdam

Mcavoy, T. (2002) Model predictive statistical process control of chemical plants. Ind. Eng. Chem. Res. 41 (25) 6337.

OBENG, K. (1993) A study of properties of some Ghanaian clays used for the production of bricks. Journal of Building and Road Research $\mathbf{1}$ (1\&2), 12 .

Sarfo-Ansah J., Bediako, M. And Atiemo, E. (2009) Affordable housing in Ghana using pozzolana as partial substitutes to Portland cement. World Cement 40 (9), 163.

Taverniers, I., De Loose, M. \& Van Bockstaele, E. (2004) Trends in quality in the analytical laboratory II. Analytical method validation and quality assurance. Trends in Analytical Chemistry 23 (8), 535.

Westgard, J. O., Barry, P. L., Hunt, M. R. And GroTH, T. (1981) A multi-rule Shewhart chart for quality control in clinical

Received 4 Apr 16; revised 31 Jan 20. 